\title{
CHARACTERIZATION OF RECYCLED GLASS-CEMENT COMPOSITE: MECHANICAL STRENGTH
}

\author{
KARAKTERIZACIJA KOMPOZITA, IZDELANEGA IZ \\ RECIKLIRANEGA STEKLA IN CEMENTA: MEHANSKA TRDNOST
}

\author{
Waldemar Lasica, Marcin Małek*, Zbigniew Szcześniak, Mariusz Owczarek \\ Military University of Technology in Warsaw, Faculty of Civil Engineering and Geodesy, 2 gen. Sylwestra Kaliskiego, 00-908 Warsaw, Poland
}

Prejem rokopisa - received: 2019-07-15; sprejem za objavo - accepted for publication: 2020-02-27

doi:10.17222/mit.2019.152

\begin{abstract}
The presented work summarizes the results for the mechanical strength of a recycled glass-cement composite. The composite material was fabricated using Portland cement CEM I $52.5 \mathrm{~N}$. As the aggregate, $100-\%$ recycled glass bottles were added. The novelty of the research was to fabricate a cement composite using only recycled glass as the aggregate. This type of glass has many imperfections in its structure. In addition, it also contains elements used as fluxes that chemically pollute the glass. Due to this, the described glass is very difficult to recycle and requires many pre-trial procedures before the recycling process. The final recipe was prepared with the experimental-laboratory method, using the following aggregates: $0 / 2 \mathrm{~mm}$ of glass bottles, $0 / 0.2 \mathrm{~mm}$ of glass flour, a deflocculant based on polyacrylate and a hydrophobic additive based on surfactants. In this work, three kinds of recycled glass-cement composite were compared (the reference one, a composite with a zeolite addition and a composite with a fly-ash addition to the matrix). The main purpose of this research was to increase the use of difficult-to-recycle materials such as bottle glass and fly ash in industry. After 28 days of curing, the mechanical properties including the compressive strength, bending strength and tensile strength were widely investigated. Light micrographs of the additives were characterized. Additionally, the thermal properties were measured. The used glass aggregates increased the mechanical strength and thermal properties of the fabricated composites. These kinds of composites are very suitable for future applications in civil engineering in special-building construction.

Keywords: concrete strength, recycled glass, glass-cement composite, mechanical strength
\end{abstract}

$\mathrm{V}$ pričujočem prispevku avtorji podajajo povzetek rezultatov preiskav mehanske trdnosti kompozita, sestavljenega iz recikliranega stekla in cementa. Kompozitni material je bil izdelan z uporabo portlandskega cementa CEM I 52,5 N. Kot agregat so bile uporabljene samo reciklirane steklenice. Novost raziskave je v tem, da so avtorji za izdelavo steklo-cementnega kompozita, kot agregata uporabili samo reciklirano steklo. Ta vrsta stekla ima mnogo napak v svoji strukturi. Še dodatno, takšno steklo vsebuje različne vrste elementov iz talil, ki onesnažujejo steklo. Zato je takšno steklo zelo težko reciklirati, saj je potrebno pred reciklažo izvesti več preizkusov oz. predhodnih postopkov. Končni recept za izdelavo kompozita so avtorji izračunali z uporabo eksperimentalnih laboratorijskih metod z vključitvijo: stekleničnega drobirja velikosti do $2 \mathrm{~mm}$, fluoridnega stekla velikosti do $0,2 \mathrm{~mm}$, deflokulanta (antipenilca) na osnovi poliakrilata in površinsko aktivnih snovi, ki odbijajo vodo (hidrofobnega dodatka na osnovi surfaktantov). V raziskavi so primerjali tri vrste izdelanih kompozitov steklo-cement s kompozitom, ki je kot matrico vseboval zeolit z dodatkom dimniškega pepela. Glavni namen raziskave je bil določiti, kako v industriji povečati uporabo trdih recikliranih materialov, kot so steklenice in dimniški pepel. Po 28-tih dneh sušenja, so avtorji določili mehanske lastnosti (tlačno, upogibno in natezno trdnost) izdelanih kompozitov. Dodatno so kompozite pregledali s svetlobnim mikroskopom in določili njihove termične lastnosti. Uporabljeni stekleni agregati so povečali mehansko trdnost in izboljšali termične lastnosti izdelanih kompozitov. Ta vrsta kompozitov ima veliko možnosti, da bodo v prihodnje uporabljeni v gradbeništvu, še posebej za specialne gradbene konstrukcije.

Ključne besede: trdnost betona, reciklirano steklo, kompozit steklo-cement, mehanska trdnost

\section{INTRODUCTION}

Granulated glass together with ground sand may be a partial substitute for the cement binder in an amount of up to $15 \%$ in relation to the planned amount of cement in a concrete mix. Glass powder affects the strength of concrete, not only after 28 days in relation to the reference concrete, but also in the later period of concrete maturation. ${ }^{1-6}$

Designing ecological, self-compacting concrete provided for a new possibility of introducing waste-glass powder into the composition of a composite. Glass powder has been used in SCC (self-compacting concrete)

*Corresponding author's e-mail:

marcin.malek@wat.edu.pl (Marcin Małek) types that do not require additional mechanical compaction, reducing the costs of the technology for concrete and reinforced-concrete structures. Glass powder improves the rheological properties of a fresh concrete mix, allowing excellent workability - the ability to accurately fill in the moulds and frameworks without the use of thickening devices. Experimental studies have proved the possibility of using a larger range of plasticizers compatible with glass powder. ${ }^{7-12}$

The use of glass waste in transparent and photocatalytic concrete leads to the construction of innovative composites that purify the air of oxides and nitrogen oxides. The literature demonstrates the influences of purified and impurified glass in the structure of such concrete on its photocatalytic capabilities. ${ }^{13-15}$ 
The development of an ultra-high-speed composite using glass powder is a new trend towards eco-concrete with a compressive strength of over $220 \mathrm{MPa}$. Glass in the powder form, more precisely, glass dust, affects the mechanical and microstructural properties of concrete. The concrete of this type was defined as UHPGC (ultra-high-performance glass composite). The UHPGC concrete has technological, economic and environmental advantages compared to the ultra-resistant UHPC concrete. The UHPGC concrete is more ecological due to the reduction in the amount of cement in the composition of concrete. ${ }^{16-20}$

\section{EXPERIMENTAL PART}

Portland CEM I 52.5 N white and CEM I 52.5 R grey cements were used to make all the samples (low-alkaline cements with a low chloride content). In addition, an acrylate-based water-reducing agent was used. Three recipes were prepared: the reference sample, based on the glass aggregate, with a zeolite addition of $13.5 \mathrm{w} / \%$ (Recipe 2) and with a fly-ash addition of $13.5 \mathrm{w} / \%$ (Recipe 3) to improve the workability of the composite and make it possible to include additional waste materials. All tests and sample preparations were performed in accordance with the applicable European standards for concrete.

\subsection{A mixture of cement and glass}

The cement-and-glass composite consistency test was performed with the drop-cone method.

The $\mathrm{pH}$ value was tested using a $\mathrm{pH}$ meter with a probe used for suspensions at $21{ }^{\circ} \mathrm{C}$ and 50-\% humidity. For the measurement, we used a high chemical glass reactor, which was filled with a sample of a fresh mixture of cement and glass. The sample of the mixture was dissolved in water in a ratio of 1:2.5 (the ratio of the mixture to water: $250 \mathrm{~g}$ of water and $100 \mathrm{~g}$ of the mixture). In order to obtain a homogenous suspension, the amount of glass was mixed with water using a magnetic stirrer with high rotations.

An analysis of the air-pore amount was made using the pressure method. Determination of the amount of air pores in a sample of a fresh mix of cement and glass was made using an 8-litre porosimeter.

\subsection{Cement-glass composite after 28 days of matu- ration}

The strength of cement-and-glass samples was determined with three-point bending, compression and tensile tests. For this purpose, standard samples were used. A strength machine was used for the strength tests. The transverse speed was set at $5 \mathrm{~mm} /$ minute. The values of Young modulus and Poisson's ratio were also determined.
Research was carried out in the field of determining the basic thermal parameters. The individual thermal parameters, i.e., the values of thermal conductivity coefficient $\lambda$, specific heat per unit of volume $c_{\mathrm{pv}}$ and thermal diffusivity were measured with an ISOMET 2114 meter. The density $\rho$ of the material was also measured, using precision weight and volume measurements.

In addition, after the mechanical tests, the samples were subjected to surface-structure studies in order to determine the correctness of the choice of the vibration time and mixing. For this purpose, an Opta-Tech transmission-reflection microscope was used.

\section{RESULTS AND DISCUSSIONS}

The obtained samples and recycled glass aggregate are shown in Figure 1.

In the photographs below, it can be observed that the glass grains are sharp-edged. There are several fractions of powder, which were subjected to a mechanical breakage before the calculation of the recipe and then sifted using an automatic sift device. This allowed us to separate the fractions in the form of glass flour from the 0-2 $\mathrm{mm}$ aggregates.

The surface of the produced cement-glass composite, i.e., its cross-section does not bear any signs of poorly selected vibration time and mixing time. The particles are evenly distributed and do not form aggregates (agglomerates). No places are observed where the cement is

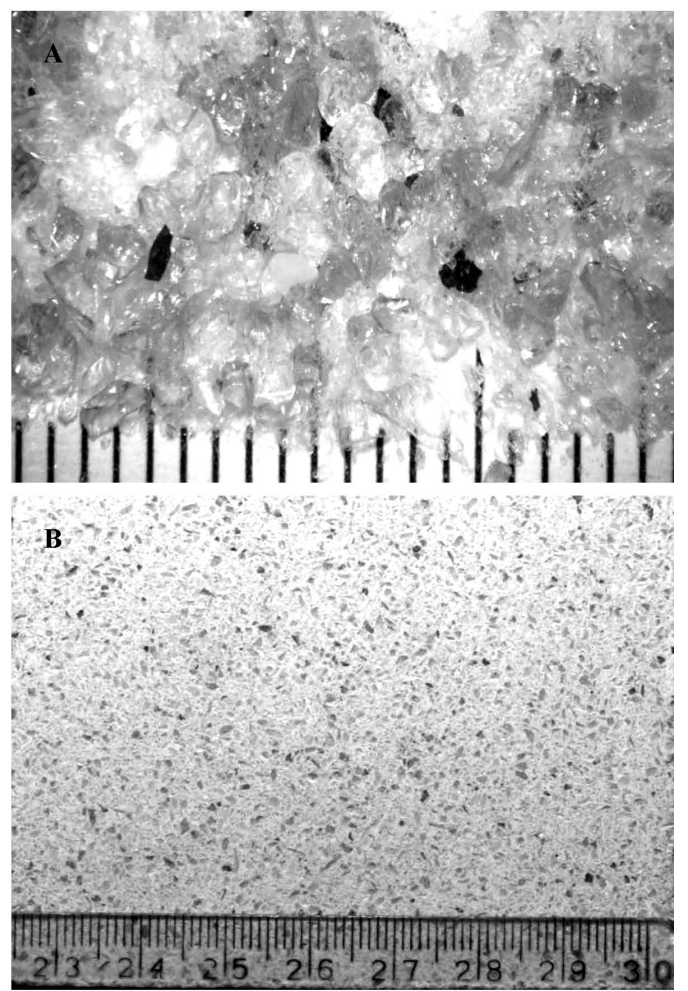

Figure 1: a) Recycled-glass surface and b) cross-section of obtained glass-cement composite 

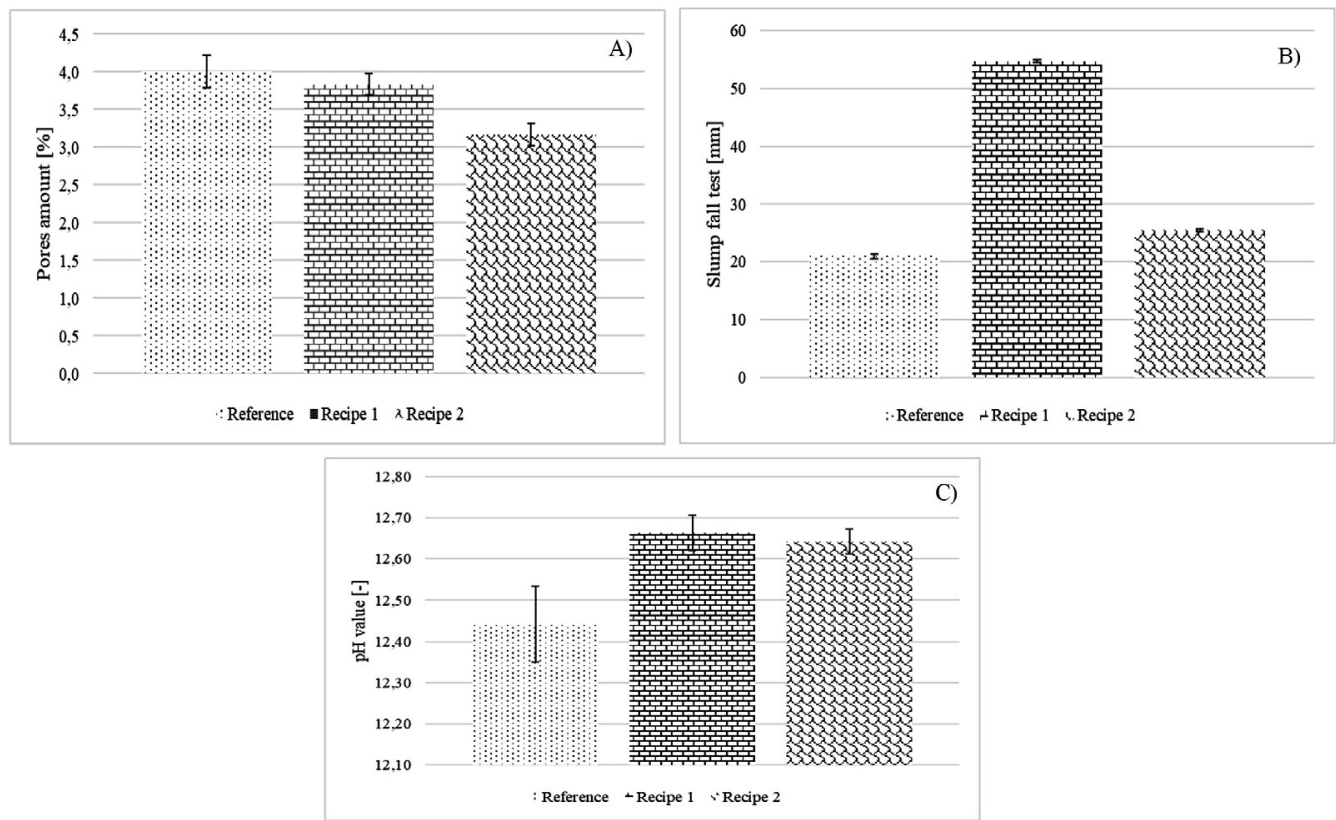

Figure 2: Basic properties of mortars (A - pores B - average values of the slump test, $\mathrm{C}-\mathrm{pH}$ values)
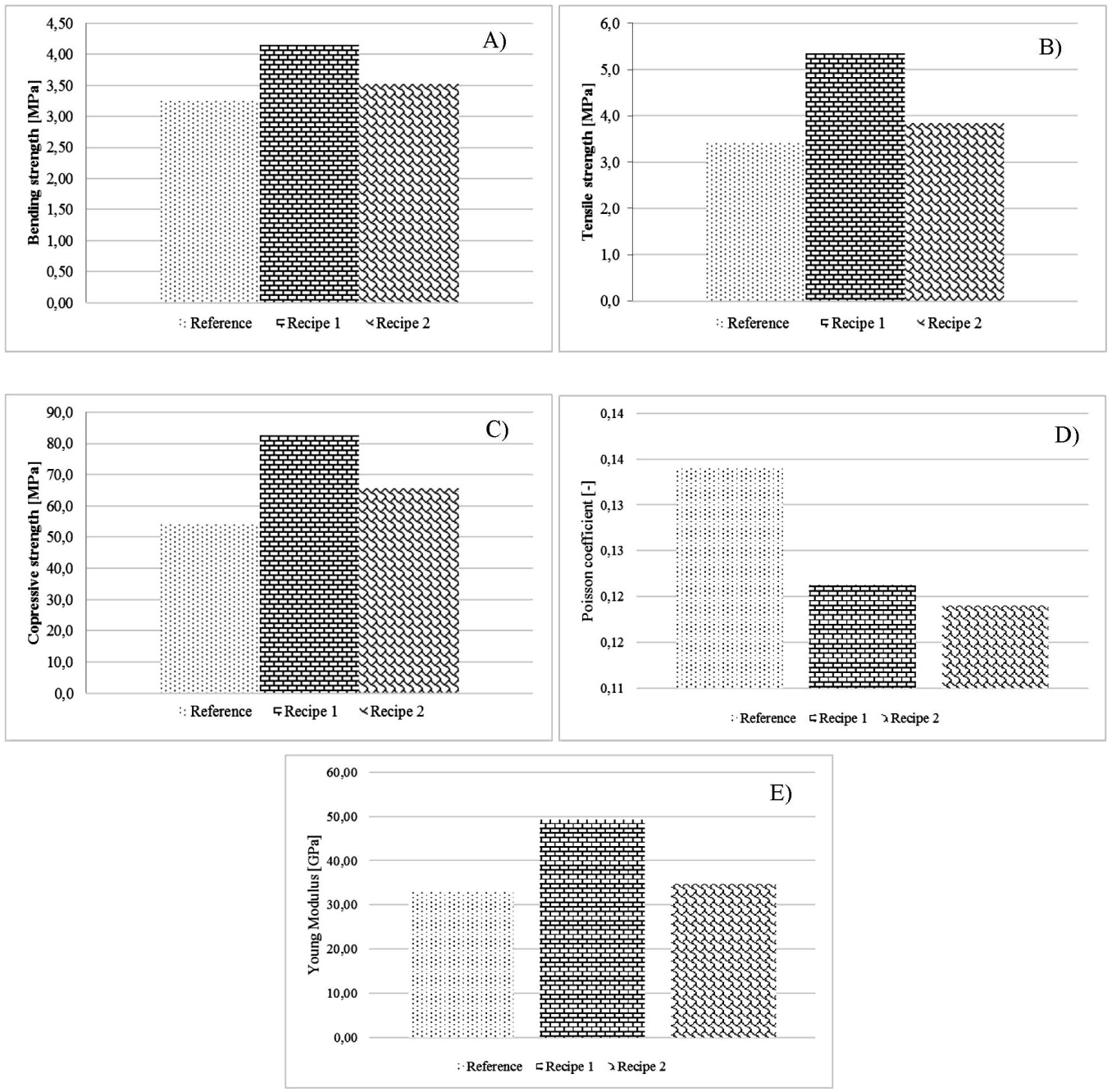

Figure 3: Mechanical-strength comparison for investigated glass-cement composites (A - bending strength, B - tensile strength, $\mathrm{C}-$ compressive strength, D - Poisson's ratio, E - Young's modulus) 
not bonded. This is a sign of a well-prepared sample, which undoubtedly has a large impact on the final properties of the prepared glass-cement composite.

The basic parameters such as the pore amount, slump test and $\mathrm{pH}$ value compared for the investigated glasscement composite samples are presented in Figure 2.

The above graphs show that Recipe 2 with the addition of zeolite is characterized by the highest $\mathrm{pH}$ value (12.66) and a drop of the Abrams cone to the level above $50 \mathrm{~mm}$. This is evidenced by the fact that this sample represents the $\mathrm{S} 2$ consistency. The remaining products are characterized by the $\mathrm{S} 1$ consistency. The highest pore content is shown by the reference-recipe sample amounting to $4 \%$.

Mechanical-strength comparisons involving the bending strength, tensile strength, compressive strength, Poisson's ratio and Young's modulus are shown in Figure 3.

According to the following graphs, the Recipe 1 sample shows the highest mechanical resistance among all the cement-glass composites produced. Because $13.5 \%$ of zeolite was used for its production, it allowed for its better sealing, thus increasing the resistance to compression, bending and stretching during splitting. The addition of fly ash, in the Recipe 2 sample, also increased the strength of the obtained concrete. In the reference sample, in which the glass flour was used as its smallest fraction, the same strength as the designed one was observed. Both the Poisson's ratio and Young's modulus confirm this relationship. The produced samples were characterized by the strength class: C50/60, C80/95 and C60/75, respectively.

The results of the thermal tests, i.e., the density, thermal conductivity, heat capacity and thermal diffusivity, for the samples of the cement-glass composite are presented in Table 1.

Table 1: Thermal properties of investigated samples

\begin{tabular}{|c|c|c|c|c|c|}
\hline No. & Recipe & $\begin{array}{c}\text { Density } \\
\left(\mathrm{kg} / \mathrm{m}^{3}\right)\end{array}$ & $\begin{array}{c}\text { Thermal } \\
\text { conductivity } \\
(\mathrm{W} /(\mathrm{mK}))\end{array}$ & $\begin{array}{c}\text { Heat } \\
\text { capacity } \\
(\mathrm{J} /(\mathrm{kgK})\end{array}$ & $\begin{array}{c}\text { Thermal } \\
\text { diffusivity } \\
\left(\mathrm{m}^{2} / \mathrm{s}\right)\end{array}$ \\
\hline 1 & Reference & 2304 & 1.11 & 727 & $6.63 \mathrm{e}-7$ \\
\hline 2 & Recipe 1 & 2095 & 0.98 & 745 & $6.54 \mathrm{e}-7$ \\
\hline 3 & Recipe 2 & 2057 & 0.97 & 760 & $6.30 \mathrm{e}-7$ \\
\hline 4 & $\begin{array}{c}\text { Normal } \\
\text { quartz- } \\
\text { sand-based } \\
\text { concrete }\end{array}$ & 2400 & 2.35 & 705 & $1.39 \mathrm{e}-6$ \\
\hline
\end{tabular}

Reduced values of the thermal-conduction coefficient depended mainly on the glass aggregate and glass flour used. Comparing the cement-glass composite to the sand-gravel concrete, the value of the thermal-conduction coefficient decreased 2.4 times. The smallest value of this coefficient was obtained for the samples made in accordance with Recipe 2 containing fly ash from a power plant in its structure. All the tested samples exhibited much lower thermal properties, putting the concrete made in this was in a very advantageous position with respect to the current EU environmental requirements.

\section{CONCLUSIONS}

Due to one of the most demanding methods of concrete design, the iterative method, the strength designed at the $\mathrm{C} 50 / 60$ level is the highest strength obtained with this method, requiring a very well selected detrital composition of the mixture. Bottle soda glass, obtained entirely from recycled glass bottles, which are not processed due to unwanted elements in their structures, was used. However, this material met the requirements and allowed us to obtain very high classes of concrete strength. The grinding-and-sifting process is time-consuming, but with the use of the smallest fraction of other than the glass flour, it was proven that in addition to the recycled glass, additions of zeolite and fly ash also provide for an increase in the concrete strength by two and one class, respectively, creating an opportunity for even more waste to be included in the concrete structure.

Granulated glass, the recycled material of soda glass (a post-consumer material), resulting from the processing of cullet, can be an alternative substitute for natural or broken rock aggregates used for concrete and other composites based on the cement binder.

In terms of heat, the mixture was compared with the standard sand and gravel concrete. A lower conductivity was obtained, thus a better thermal insulation and a lower density. The specific heat, in comparison with concrete, increased; however, we cannot say that we obtained accumulative properties. The decrease in the thermal-conduction coefficient was affected by the absence of the traditional aggregate. On this basis, it can be deduced that the aggregate is the basic component responsible for the thermal conductivity of concrete. The mixtures obtained constitute a good base for future activities towards increasing the thermal accumulation.

After a series of endurance tests performed in the field of static loads, we plan further research on large beam elements reinforced with composite rods of the FRP type and studies of the dynamic impact and explosive loads applied to structural elements.

\section{Acknowledgment}

The financial support from the Research Statutory Program financed by the Military University of Technology, Faculty of Civil Engineering and Geodesy, called "Research of materials and construction elements of military infrastructure special objects", No. 886/2019, is gratefully acknowledged.

\section{REFERENCES}

${ }^{1}$ S. Ramdani, A. Guettala, M. L. Benmalek, J. B. Aguiar, Physical and mechanical performance of concrete made with waste rubber 
aggregate, glass powder and silica sand powder, Journal of Building Engineering, 21 (2019), 302-311, doi:10.1016/j.jobe.2018.11.003

${ }^{2}$ A. Hendi, D. Mostofinejad, A. Sedaghatdoost, M. Zohrabi, Mix design of the green self-consolidating concrete: Incorporating the waste glass powder, Construction and Building Materials, 199 (2019) 28, 369-384, doi:10.1016/j.conbuildmat.2018.12.020

${ }^{3}$ P. Spiesz, S. Rouvas, H. J. H. Brouwers, Utilization of waste glass in translucent and photocatalytic concrete, Construction and Building Materials, 128 (2016), 436-448, doi:10.1016/j.conbuildmat.2018. 12.020

${ }^{4}$ L. Yanga, A. Hakki, L. Zheng, M. R. Jones, F. Wanga, D. E. Macphee, Photocatalytic concrete for NOx abatement: Supported $\mathrm{TiO} 2$ efficiencies and impacts, Cement and Concrete Research, 116 (2019), 57-64, doi:10.1016/j.cemconres.2018.11.002

${ }^{5}$ J. L. García, Calvo P. Carballosa, A. Castillo, D. Revuelta, J. P. Gutiérrez, M. Castellote, Expansive concretes with photocatalytic activity for pavements: Enhanced performance and modifications of the expansive hydrates composition, Construction and Building Materials, 218 (2019), 394-403, doi:10.1016/j.conbuildmat.2019. 05.135

${ }^{6}$ D. E. Macphee, A. Folli, Photocatalytic concretes - The interface between photocatalysis and cement chemistry, Cement and Concrete Research, 85 (2016), 48-54, doi:10.1016/j.cemconres.2016.03.007

${ }^{7}$ L. Yang, A. Hakki, F. Wang, D. E. Macphee, Photocatalyst efficiencies in concrete technology: The effect of photocatalyst placement, Applied Catalysis B: Environmental, 222 (2018), 200-208, doi:10.1016/j.apcatb.2017.10.013

${ }^{8}$ N. A. Soliman, A. Tagnit-Hamou, Development of ultra-high-performance concrete using glass powder - Towards eco-friendly concrete, Construction and Building Materials, 125 (2016) 30, 600-612, doi:10.1016/j.conbuildmat.2016.08.073

${ }^{9}$ Y. Shi, G. Long, C. Ma, Y. Xie, J. He, Design and preparation of ultra-high performance concrete with low environmental impact, 214 (2019), 633-643, doi:10.1016/j.jclepro.2018.12.318

${ }^{10}$ V. Vaitkevičius, E. Šerelis, H. Hilbig, The effect of glass powder on the microstructure of ultra high performance concrete, Construction and Building Materials, 68 (2014), 102-109, doi:10.1016/ j.conbuildmat.2014.05.101

${ }^{11}$ D. Harbec, A. Zidol, A. Tagnit-Hamou, F. Gitzhofer, Mechanical and durability properties of high performance glass fume concrete and mortars, Construction and Building Materials, 134 (2017), 142-156, doi:10.1016/j.conbuildmat.2016.12.018

${ }^{12}$ I. Sun Kim, S. Yeong Choi, E. Ik Yang, Evaluation of durability of concrete substituted heavyweight waste glass as fine aggregate, Construction and Building Materials, 184 (2018), 269-277, doi:10.1016/j.conbuildmat.2018.06.221

${ }^{13}$ S. Yeong Choi, Y. Suk Choi, E. Ik Yang, Characteristics of volume change and heavy metal leaching in mortar specimens recycled heavyweight waste glass as fine aggregate, Construction and Building Materials, 165 (2018), 424-433, doi:10.1016/j.conbuildmat. 2018.01.050

${ }^{14}$ H. Yung Wang, W. Liang Huang, Durability of self-consolidating concrete using waste LCD glass, Construction and Building Materials, 24 (2010) 6, 1008-1013, doi:10.1016/j.conbuildmat.2009. 11.018

${ }^{15}$ H. Yung Wang, W. Liang Huang, A study on the properties of fresh self-consolidating glass concrete (SCGC), Construction and Building Materials, 24 (2010) 4, 619-624, doi:10.1016/j.conbuildmat.2009. 08.047

${ }^{16}$ Z. Jamroży, Concrete and its technologies, PWN Scientific Publishing House, Warsaw, 3 (2008)

${ }^{17}$ H. Dondolewski, M. Januszewki, Cement concrete. Selected issues, Scientific and Technical Publishing House 2019

${ }^{18}$ K. Zieliński, Fundamentals of concrete technology, Publisher of the Poznan University of Technology, $4^{\text {th }}$ complete edition, Poznań 2015

${ }^{19}$ E. Gantner, W. Chojczak, Construction materials. Binders, aggregates, mortars. Laboratory exercises, OWPW Publishing House, Warsaw 2013

${ }^{20}$ J. Jasiczak, A. Wdowska, T. Rudnicki, Ultra-high-value concretes properties, technologies, applications, Association of Cement Manufacturers, Kraków 2008 